\title{
Exploring halide destabilised calcium hydride as a high- temperature thermal battery
}

M. Veronica Sofianos ${ }^{a, *}$, Samuel Randalla, Mark Paskeviciusa ${ }^{a}$, Kondo-Francois AgueyZinsou $^{\mathrm{b}}$, Matthew R. Rowles ${ }^{\mathrm{c}}$, Terry D. Humphries ${ }^{\mathrm{a}}$, Craig E. Buckley ${ }^{\mathrm{a}}$

${ }^{a}$ Fuels and Energy Technology Institute, Curtin University, GPO Box U1987, Perth, WA 6845, Australia

${ }^{\mathrm{b}}$ MERLin Group, School of Chemical Engineering, The University of New South Wales, Sydney, NSW 2052, Australia

'John de Laeter Centre, Curtin University, GPO Box U1987, Perth, WA, 6845, Australia

*Dr Maria Veronica Sofianos

Fuels and Energy Technology Institute,

Physics and Astronomy,

Curtin University,

GPO Box U1987,

Perth, WA 6845,

Australia.

E-mail: mvsofianou@gmail.com

Fax: +61 892662377

Tel: +61 892661534 


\section{Abstract}

$\mathrm{CaH}_{2}$ is a metal hydride with a high energy density that decomposes around $1100{ }^{\circ} \mathrm{C}$ at $1 \mathrm{bar}$ of $\mathrm{H}_{2}$ pressure. Due to this high decomposition temperature, it is difficult to utilise this material as a thermal battery for the next generation of concentrated solar power plants, where the currently targeted operational temperature is between 600 and $800{ }^{\circ} \mathrm{C}$. In this study, $\mathrm{CaH}_{2}$ has been mixed with calcium halide salts $\left(\mathrm{CaCl}_{2}, \mathrm{CaBr}_{2}\right.$ and $\left.\mathrm{CaI}_{2}\right)$ and annealed at $450{ }^{\circ} \mathrm{C}$ under 100 bar of $\mathrm{H}_{2}$ pressure to form $\mathrm{CaHCl}, \mathrm{CaHBr}$ and $\mathrm{CaHI}$. These hydride-halide salts incur a thermodynamic destabilisation of their hydrogen release, compared to $\mathrm{CaH}_{2}$, so that they can operate between $600-800{ }^{\circ} \mathrm{C}$ within practical operating pressures $\left(1-10\right.$ bar $\left.\mathrm{H}_{2}\right)$ for thermochemical energy storage. The as-synthesised metal hydrides were studied by in-situ synchrotron X-ray diffraction, temperature programmed desorption and pseudo pressure composition isothermal analysis. Each of the calcium hydride-halide salts decomposed to form calcium metal and a calcium halide salt after hydrogen release. In comparison to pure $\mathrm{CaH}_{2}$, their decomposition reactions were faster when heated up to $850{ }^{\circ} \mathrm{C}$, and the experimental values of the desorbed hydrogen gas were very close to the theoretical ones. All samples after their decomposition showed signs of sintering, which hindered their rehydrogenation reaction.

Keyword: Calcium Hydride; Destabilisation; Thermochemical heat storage; Concentrated solar power

\section{Introduction}

Efficient and cost-effective energy storage is the main challenge towards providing reliable renewable energy that will eventually replace fossil fuel power. Concentrated solar power (CSP) is highly efficient, cost-effective, and can be easily scaled up [1-4]. Most importantly, with the integration of a thermal energy storage system, heat can be stored during daylight 
hours and released during periods of poor or absent solar irradiation. This allows concentrated solar power plants to produce electricity night and day cheaply to meet grid demand $[5,6]$.

There are three kinds of conventional thermal energy storage systems. i) Sensible energy storage harnesses energy from the specific heat of a material during temperature excursions of a storage medium such as "solar salts" [7-10]. Sensible energy storage is currently the most commonly used technology, with a wide range of inexpensive materials available. Nevertheless, these materials have a low energy density $(0.02-0.03 \mathrm{kWh} / \mathrm{kg})$, which necessitates large thermal energy storage systems that ultimately raise the cost of concentrated solar power plants. ii) Latent heat storage extracts energy during the changing of phase of a material, such as solid-liquid phase changes in a eutectic salt [11-13]. Latent heat has a higher energy density $(0.05-0.1 \mathrm{kWh} / \mathrm{kg})$ than sensible heat but the majority of the materials currently investigated have poor heat-transfer performance due to low thermal conductivity, along with significant energy loss. iii) Thermochemical energy storage is the most promising, but is the least commercially advanced of the three technologies [14-17]. The key benefit is its high energy density $(0.5-1.0 \mathrm{kWh} / \mathrm{kg})$, relieving the necessary mass/volume of materials and space requirements, and total cost, imposed by the other two types of systems [18-29].

Currently, there has been a great effort from the U.S. Department of Energy through the SunShot initiative, to enable the third generation of CSP plants to be operating by 2030 [3032]. The objectives of the project are to decrease the cost of the CSP plants by raising the temperature $\left(600-800^{\circ} \mathrm{C}\right)$ of the heat they deliver to the power cycle. This will reduce the cost of the new CSP systems by $40 \%$ in comparison to the existing ones that operate at $300-550^{\circ}$ $\mathrm{C}$ [33]. The higher power cycle efficiencies achieved between 600 and $800{ }^{\circ} \mathrm{C}$ are almost $50 \%$ higher than the existing ones [33, 34].

Thermal batteries that can operate at the required temperatures $\left(600-800{ }^{\circ} \mathrm{C}\right)$ for the third generation CSP plants, are currently not commercially available. Metal hydrides are promising 
candidates for thermochemical heat storage between 600 and $800{ }^{\circ} \mathrm{C}$, with some exceeding the energy density by eight times of that currently available in molten salts $[35,36]$. Calcium hydride is a high temperature metal hydride with a melting point of $816^{\circ} \mathrm{C}$, at $1000{ }^{\circ} \mathrm{C}$ with an equilibrium pressure of 1.2 bar, its experimental enthalpy $(\Delta H)$ is $207.9 \mathrm{~kJ} / \mathrm{mol} \mathrm{H}_{2}$ and entropy $(\Delta S)$ is $161.81 \mathrm{~J} / \mathrm{mol} \cdot \mathrm{K}[35,37-39]$. Metal hydrides can release and absorb hydrogen at certain temperatures based on their thermodynamics. $\mathrm{CaH}_{2}$ exhibits low operating pressures ( $1-5$ bar) when heated to $1100-1400{ }^{\circ} \mathrm{C}$, and has a high theoretical gravimetric energy density equal to $4426 \mathrm{~kJ} \mathrm{~kg}^{-1}$ [35]. Calcium hydride has several industrial applications and is widely used as a desiccant in laboratory practice for extracting moisture from crystal hydrates, hydrocarbons, ethers and other solvents $[40,41]$. It is also commonly used as a reducing agent for the synthesis of metallic powders such as $\mathrm{Ti}, \mathrm{Zr}, \mathrm{Nb}$, Ta, Mo and $\mathrm{W}$ from their oxides and halides $[42,43]$. The main factors that hinder the utilisation of calcium hydride as a high temperature thermal battery is its high operating temperature $\left(\sim 1100{ }^{\circ} \mathrm{C}\right)$ that increase the costs of the tank materials and engineering [35].

A frequent method applied to thermodynamically destabilising a metal hydride and to decompose it at lower temperatures is to substitute a hydrogen atom with a halide such as fluorine in its crystal structure $[28,44]$. Halide substitution using chlorine, bromine or iodine in calcium hydride has not been widely investigated, most likely due to the difficulties in measuring metal hydride compounds at high temperatures [45]. In 1956, Ehrlich et. al investigated the structural properties of $\mathrm{CaHCl}$, which was furthered by Beck et. al in 1983, but there is little information available on the suitability of these hydrides as heat storage materials [46, 47]. In 1987, Ayadi et. al studied the crystal growth of $\mathrm{CaHCl}$ and $\mathrm{CaDCl}$ using Raman spectroscopy [48], while Sridharan et. al studied the phase relationship and electrical properties of $\mathrm{CaCl}_{2}-\mathrm{CaH}_{2}$ [49]. Vardhan et. al studied the phase diagram of $\mathrm{CaBr}_{2}-\mathrm{CaHBr}$ in 
$2013[49,50]$, although there aren't any studies on the CaHI system and none regarding the thermodynamic properties of any of the halide-hydride systems.

In this work, $\mathrm{CaH}_{2}$ was mixed with $\mathrm{CaCl}_{2}, \mathrm{CaBr}_{2}$ and $\mathrm{CaI}_{2}$ to form $\mathrm{CaHCl}, \mathrm{CaHBr}$ and $\mathrm{CaHI}$, respectively. The potential of these calcium hydride-halides systems as thermochemical energy storage materials utilised in concentrated solar thermal power plants operating between 600 and $800{ }^{\circ} \mathrm{C}$ is investigated and reported.

\section{Materials and methods}

\subsection{Sample preparation}

All sample preparation and handling was performed using an Ar glovebox (Mbraun Unilab) with $\mathrm{O}_{2}$ and $\mathrm{H}_{2} \mathrm{O}$ concentrations of less than $1 \mathrm{ppm}$, since all chemicals used for the synthesis were sensitive to both air and moisture. $\mathrm{CaH}_{2}$ (Sigma Aldrich, $\geq 95 \%$ ) was ball-milled with $\mathrm{CaCl}_{2}($ Sigma Aldrich, $\geq 93 \%), \mathrm{CaBr}_{2}($ Sigma Aldrich, $\geq 98 \%)$ and $\mathrm{CaI}_{2}$ (Sigma Aldrich, $\geq$ $99 \%$ ) respectively in a 1:1 molar ratio for $10 \mathrm{~h}$ under argon at $400 \mathrm{rpm}$. The ball to powder mass ratio was 40:1 using 316 stainless steel canisters $(100 \mathrm{ml})$, and an equal mixture of 10 and $6 \mathrm{~mm}$ stainless steel balls. After milling, the $\mathrm{CaH}_{2}-\mathrm{CaCl}_{2}, \mathrm{CaH}_{2}-\mathrm{CaBr}_{2}$ and $\mathrm{CaH}_{2}-\mathrm{CaI}_{2}$ mixtures were annealed at $450{ }^{\circ} \mathrm{C}$ under 100 bar $\mathrm{H}_{2}$ for 12,24 and $48 \mathrm{~h}$, respectively to form $\mathrm{CaHCl}, \mathrm{CaHBr}$ and $\mathrm{CaHI}$ as verified by powder $\mathrm{X}$-ray diffraction.

\subsection{Sample characterisation}

In-situ synchrotron radiation X-ray powder diffraction (SR-XRD) was performed at the Australian Synchrotron [51]. All samples were loaded in quartz capillaries (outer diameter 0.7 $\mathrm{mm}$ and wall thickness $0.05 \mathrm{~mm}$ ). The capillaries were mounted onto a sample holder made from Swagelok tube fittings and connected to a vacuum manifold. The capillary was heated using a hot air blower from room temperature to $900{ }^{\circ} \mathrm{C}$ with a $10{ }^{\circ} \mathrm{C} \mathrm{min}{ }^{-1}$ heating rate under dynamic vacuum. The temperature of the hot air blower was calibrated against the known 
thermal expansion coefficient of $\mathrm{NaCl}$ and $\mathrm{Ag}$ [52-54]. SR-XRD data was collected using a Mythen microstrip detector at two different detector positions in order to cover the entire $2 \theta$ range (10 - 40 degrees) [55]. The exposure time for each position was $30 \mathrm{~s}$, and $1 \mathrm{~min}$ in total for the entire $2 \theta$ range, $\lambda=0.589741 \AA$ for $\mathrm{CaH}_{2}$ and $\mathrm{CaHBr}$ and $\lambda=0.9218749 \AA$ for $\mathrm{CaHCl}$, and $\mathrm{CaHI}$ were used. The two different wavelengths are due to collected data that were obtained from two experiments done at the Australian Synchrotron at different times using a $21.04 \mathrm{keV}$ and $13.46 \mathrm{keV}$ energy source respectively. The selection of a different energy for the second experiment was to obtain data with a higher resolution that would help their phase analysis. A lower incident energy gives a higher angular resolution due to the spreading out of the resultant diffraction pattern.

Differential Scanning Calorimetry (DSC) and Temperature Programmed Desorption Mass Spectrometry (TPD-MS) measurements were obtained using a Mettler Toledo DSC 1 coupled with an Omnistar MS with $\pm 0.2^{\circ} \mathrm{C}$ temperature and $\pm 20 \mu \mathrm{g}$ balance accuracy. The instrument was located inside a glovebox with an Ar atmosphere to avoid oxidation of the materials during their transfer to the TGA/DSC. In each case, samples $(\sim 8 \mathrm{mg})$ were loaded in a $70 \mu \mathrm{L}$ alumina crucible and heated to $900{ }^{\circ} \mathrm{C}$ with a $10{ }^{\circ} \mathrm{C} \mathrm{min}-1$ heating rate under an Ar flow of $20 \mathrm{~mL} \mathrm{~min}{ }^{-1}$. Further volumetric TPDs and pseudo Pressure Composition Isotherms (PCI) measurements were undertaken on a computer controlled Sieverts/volumetric gas apparatus, with a $5 \mathrm{~h}$ equilibrium step and a 3 bar pressure increment $[56,57]$. The PCI measurements are referred to as "pseudo" since the kinetics for the desorption reactions were very slow, and the real equilibrium pressures during the isothermal measurements were not completely attained. Nevertheless, the obtained pseudo PCI measurements provide a good indication of the true PCIs. Sample temperature and pressure were recorded every 30 s using a K-type thermocouple with a calibrated accuracy of $\pm 1{ }^{\circ} \mathrm{C}$ at $419^{\circ} \mathrm{C}$ and a digital pressure transducer (Rosemount 3051S) with a precision/accuracy of 14 mbar. Volumetric TPD data were obtained using a 
Sievert's apparatus from room temperature to $850{ }^{\circ} \mathrm{C}$ with a ramping rate of $5^{\circ} \mathrm{C} \mathrm{min}^{-1}$ before reaching isothermal conditions at $850{ }^{\circ} \mathrm{C}$ for $4 \mathrm{~h}$. All volumetric TPD experiments were undertaken starting from vacuum and all the gas released is hydrogen $\left(0.3-0.9\right.$ bar of $\mathrm{H}_{2}$ released from the samples). Pseudo-PCI data were collected at different temperatures between 650 and $725^{\circ} \mathrm{C}$. A SiC sample cell was used for both volumetric TPD and PCI measurements to avoid hydrogen permeability at high temperature [58]. All samples were placed in alumina sample holders and then mounted inside the $\mathrm{SiC}$ sample cell.

Morphological observations were carried out with a Zeiss Neon 40EsB (Zeiss, Germany) scanning electron microscope (SEM). SEM specimens were prepared by placing a small amount of the powder sample onto carbon tape. The exposure of the samples to air was minimised by using a custom made ante chamber in which the specimens were transferred from the glovebox to the SEM chamber. Phase observations of all samples after their TPD measurements were examined by powder X-ray diffraction (XRD) (Bruker D8 Advanced diffractometer) using $\mathrm{CuK} \alpha$ radiation. The measurements were performed using $0.3^{\circ}$ for the divergence slit and $0.3^{\circ}$ for the antiscattering slit. The measured $2 \theta$ range $\left(10^{\circ}-80^{\circ}\right)$ was scanned with a 0.03 step size, at $1.6 \mathrm{~s} / \mathrm{step}$ and a rotational speed of $30 \mathrm{rpm}$. The accelerating voltage and applied current were $40 \mathrm{kV}$ and $40 \mathrm{~mA}$, respectively. XRD sample holders were covered with a poly(methylmethacrylate) (PMMA) airtight bubble to prevent oxygen/moisture contamination during data collection. This bubble results in a broad hump in XRD patterns centred at $\sim 20^{\circ} 2 \theta$.

\section{Results and discussion}

\subsection{Initial phase analysis}

X-ray diffraction patterns of $\mathrm{CaH}_{2}$ (space group Pnma) [58] and the annealed hydride-halide samples $(P 4 / \mathrm{nmm})[48]$ are presented in Fig. 1. The as-supplied $\mathrm{CaH}_{2}$ displays minor traces of 
$\mathrm{CaO}$. Calcium hydride and its derivatives are highly sensitive to oxygen and moisture. As such, all as-prepared samples have minor traces of $\mathrm{CaO}$ and some $\mathrm{Ca}(\mathrm{OH})_{2}(\mathrm{Fig} 1(\mathrm{~b}, \mathrm{c}))$. The formation of calcium hydroxide may occur from trace moisture in the calcium halide salts. In Fig. 1(b, c) $\mathrm{CaHCl}$ and $\mathrm{CaHBr}$ are the dominant phases present in the sample, indicating that the starting materials $\mathrm{CaH}_{2}-\mathrm{CaCl}_{2}$ (for $\mathrm{CaHCl}$ ) and $\mathrm{CaH}_{2}-\mathrm{CaBr}_{2}$ (for $\mathrm{CaHBr}$ ) have reacted during annealing at $450{ }^{\circ} \mathrm{C}$ at 100 bar $\mathrm{H}_{2}$ pressure for 12 and 24 hours respectively. In contrast, minor diffraction peaks of $\mathrm{CaI}_{2}$ are present in the prepared CaHI sample, even though it was annealed for $48 \mathrm{~h}$. Extended annealing times for this sample were applied in comparison to the CaHBr sample, since $24 \mathrm{~h}$ was not sufficient to form CaHI. Traces of unknown phases were identified in some of the as-synthesised samples $(\mathrm{CaHBr}$ and $\mathrm{CaHI})$, therefore a reliable quantitative Rietveld analysis of all present phases could not be performed. 


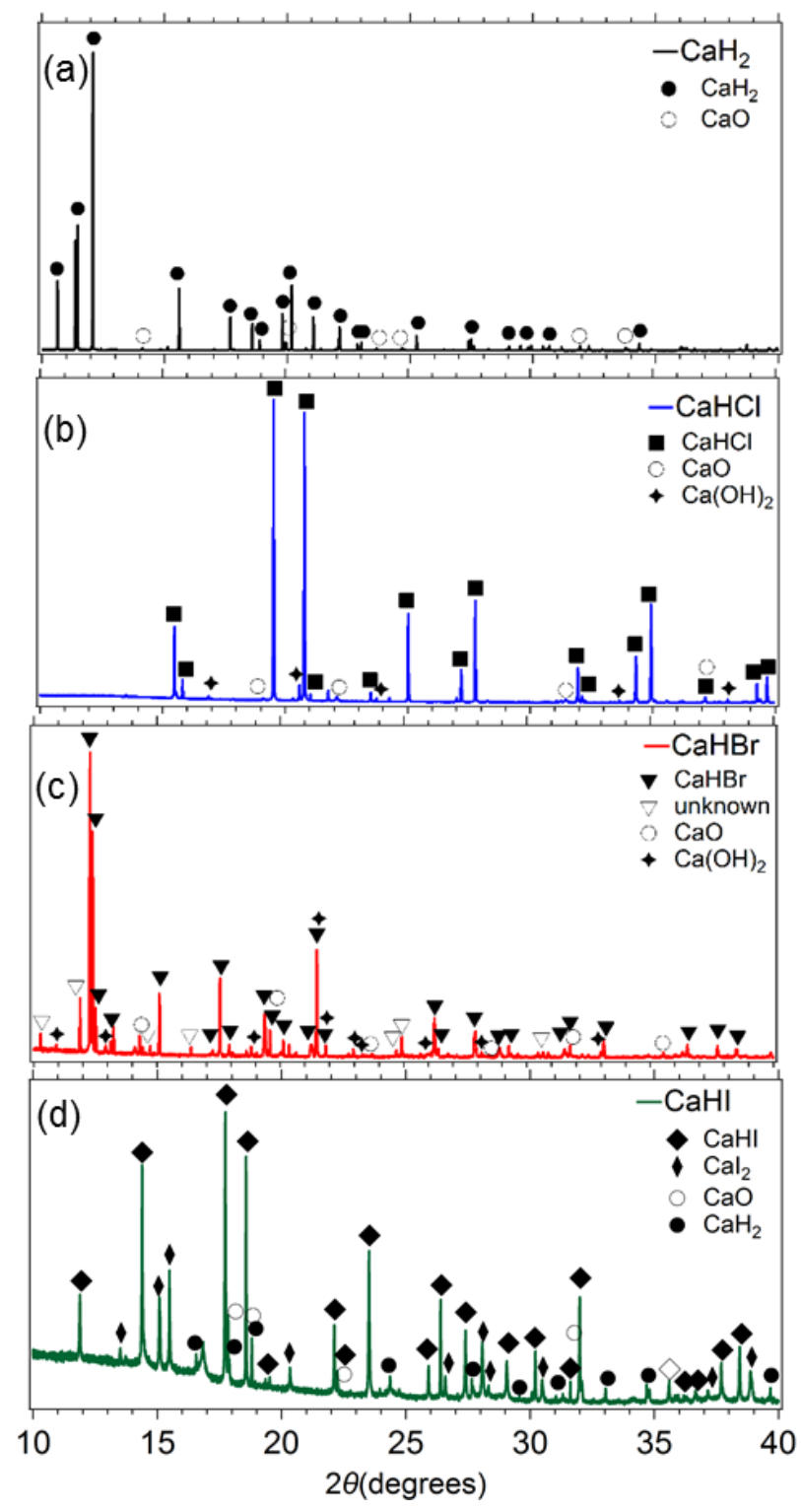

Fig. 1: Ex-situ SR-XRD patterns at room temperature for (a) $\mathrm{CaH}_{2}(\lambda=0.589741 \AA)$ (b) the asprepared $\mathrm{CaHCl}$ annealed at $450{ }^{\circ} \mathrm{C}$ and 100 bar $\mathrm{H}_{2}$ for $12 \mathrm{~h}(\lambda=0.9218749 \AA)$, (c) $\mathrm{CaHBr}$ for 24h $(\lambda=0.589741 \AA)$ and (d) CaHI for 48h $(\lambda=0.9218749 \AA)$.

\subsection{Thermal analysis}

All four sets of in-situ SR-XRD patterns (Figs. 2-5(a)) $\left(\mathrm{CaH}_{2}, \mathrm{CaHCl}, \mathrm{CaHBr}, \mathrm{CaHI}\right)$ show an expansion of their lattice parameters (diffraction peaks decrease in $2 \theta$ ) with increased temperature (Table s1, Figs. s1 - s4). In-situ SR-XRD patterns and TPD-MS curves for $\mathrm{CaH}_{2}$ are presented in Fig. 2. The DSC data for the same sample is presented in the electronic 
supplementary information (Fig. S5). A first phase transformation is observed at $600{ }^{\circ} \mathrm{C}$ (Fig. 2(a)), where diffraction peaks of a solid solution of $\mathrm{CaH}_{x}$ appear. The formation of this phase is due to the partial decomposition of $\mathrm{CaH}_{2}$ [59]. This observation is mirrored in the TPD-MS data (Fig. 2(b)), where hydrogen commences desorption at the same temperature. The $\mathrm{CaH}_{\mathrm{x}}$ phase that appears at $600{ }^{\circ} \mathrm{C}$ disappears at $~ 800{ }^{\circ} \mathrm{C}$, in accordance with the maximum rate of hydrogen desorption observed in the TPD-MS curve (Fig. 2(b)). The expected endothermic decomposition peak of $\mathrm{CaH}_{2}$ is not observed between 600 and $700{ }^{\circ} \mathrm{C}$ in the DSC curve (Fig. S5), although the endothermic peak attributed to the melting of $\mathrm{Ca}$ at $\sim 800{ }^{\circ} \mathrm{C}$ is seen. This observation matches with the maximum rate of hydrogen desorption according to the TPD-MS curve (Fig. 2(b)). Beyond $800{ }^{\circ} \mathrm{C}$ the formation of $\mathrm{CaO}$ may be due to the presence of oxygen in the system either from a small leak in the vacuum seal or as an impurity in the material itself. This results in an instantaneous contamination reaction of $\mathrm{Ca}$ with the oxygen forming a stable oxide, during the measurement.

According to Fig. 2(b) a small amount of hydrogen is desorbed at lower temperatures than expected $\left(200-400{ }^{\circ} \mathrm{C}\right)$. This phenomena is evident in all TPD-MS (Fig. 3(b) - 5(b)) and TPD data (Fig. 6) from each sample, and it may be due to the decomposition of $\mathrm{Ca}(\mathrm{OH})_{2}$ at that temperature to $\mathrm{CaO}$ and $\mathrm{H}_{2} \mathrm{O}$. The produced water instantaneously oxidises the metal hydrides and hydrogen is released, which is detected by the mass spectrometer. 

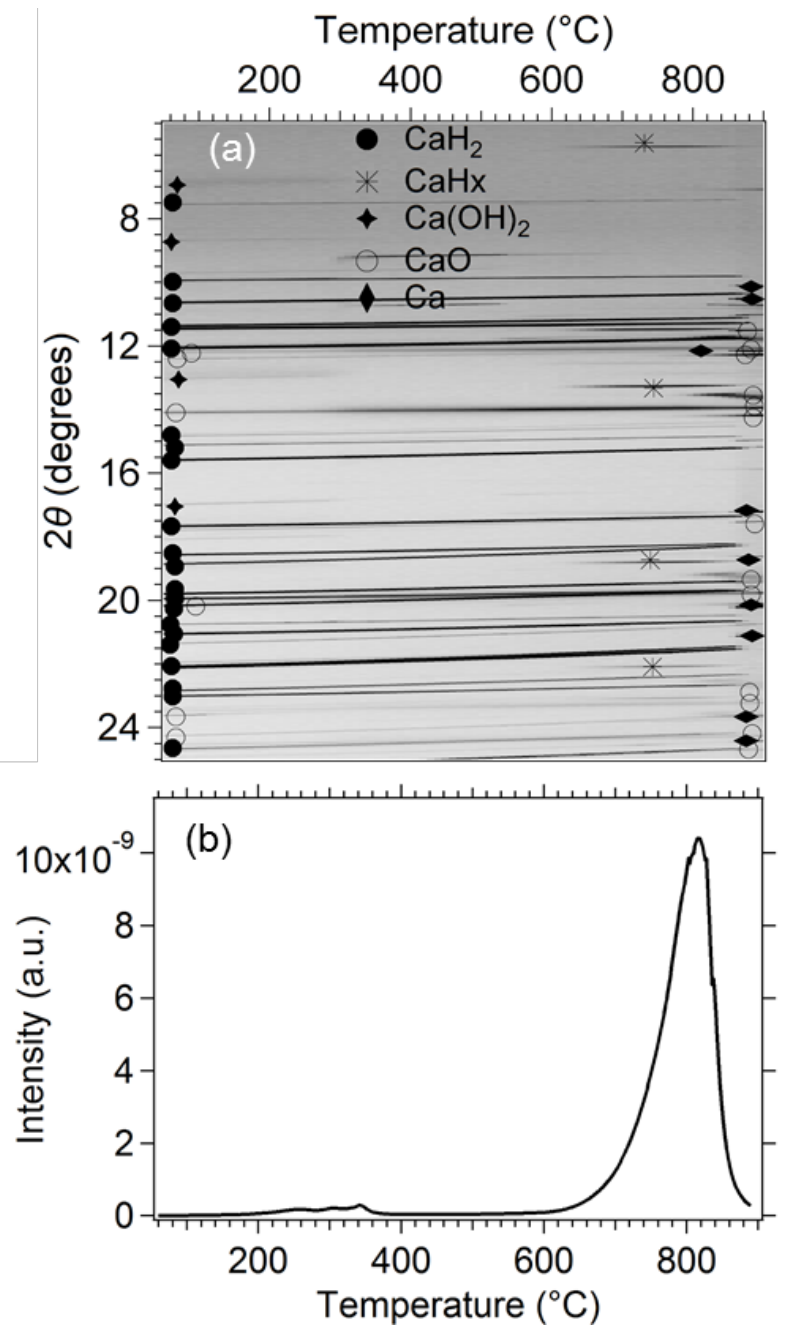

Fig. 2: $\mathrm{CaH}_{2}$ (a) In-situ SR-XRD, $\lambda=0.589741 \AA$, and (b) hydrogen desorption profile as observed by TPD-MS.

In Fig.3(a) in-situ SR-XRD patterns for $\mathrm{CaHCl}$ are presented. The diffraction peaks related to the $\mathrm{CaHCl}$ phase begin to disappear at $\sim 720^{\circ} \mathrm{C}$. At the same temperature both an endothermic peak is observed by DSC (Fig. S6), which reflects the decomposition of the $\mathrm{CaHCl}$, and a rapid hydrogen release is evident by TPD-MS (Fig. 3(b)). The formation of $\mathrm{Ca}$ and $\mathrm{CaCl}_{2}$ is expected to start after $730{ }^{\circ} \mathrm{C}$, indicating that $\mathrm{CaHCl}$ decomposes according to chemical reaction (1).

$2 \mathrm{CaHCl} \rightarrow \mathrm{Ca}+\mathrm{CaCl}_{2}+\mathrm{H}_{2}$

At $772{ }^{\circ} \mathrm{C} \mathrm{CaCl}_{2}$ is molten and therefore it is impossible to identify by in-situ SR-XRD. At the same temperature $\mathrm{CaCl}_{2} \mathrm{O}_{2}$ formation is evident, which is the reaction product of molten $\mathrm{CaCl}_{2}$ with 
oxygen. At $800{ }^{\circ} \mathrm{C} \mathrm{Ca}_{2} \mathrm{SiO}_{4}$ begins to form, which is a result of the corrosive molten Ca reacting with the quartz $\left(\mathrm{SiO}_{2}\right)$ capillary and oxygen, which failed at the end of the experiment [60]. $\mathrm{CaO}$ is present in all in-situ SR-XRD diffraction patterns from room temperature up to $900{ }^{\circ} \mathrm{C}$, which is stable in this temperature range, and results from an impurity in the staring material. $\mathrm{Ca}$ and $\mathrm{CaCl}_{2}$ were evident in the XRD pattern of the decomposed sample after the TPD measurement (Fig. S9), confirming that $\mathrm{CaHCl}$ decomposes according to reaction (1).


Fig. 3: In-situ $\mathrm{SR}-\mathrm{XRD}$ (a) for $\mathrm{CaHCl}, \lambda=0.9218749 \AA$, and (b) simultaneous thermal analysis by temperature programmed desorption-mass spectrometry (TPD-MS).

The in-situ decomposition of $\mathrm{CaHBr}$ is shown Fig. 4(a). It is evident that $\mathrm{CaHBr}$ diffraction peaks disappear at $700{ }^{\circ} \mathrm{C}$. At the same temperature, a peak maxima for hydrogen is detected by TPD-MS Fig. 4(b)), and an endothermic peak is observed by DSC (Fig. S7). CaHBr should be decomposing to $\mathrm{Ca}$ and $\mathrm{CaBr}_{2}$ as shown in reaction (2): 
$2 \mathrm{CaHBr} \rightarrow \mathrm{Ca}+\mathrm{CaBr}_{2}+\mathrm{H}_{2}$

The capillary begins to fail at $730{ }^{\circ} \mathrm{C}$, which is the temperature where $\mathrm{CaBr}_{2}$ melts. Formation of $\mathrm{CaSiO}_{4}$ commenced at the same temperature, which are the reaction products of $\mathrm{Ca}$ with the quartz $\left(\mathrm{SiO}_{2}\right)$ and oxygen. $\mathrm{Ca}$ and $\mathrm{CaBr}_{2}$ were present in the XRD pattern of the decomposed sample after the TPD measurement (Fig. S10), confirming that $\mathrm{CaHBr}$ decomposes according to reaction (2).

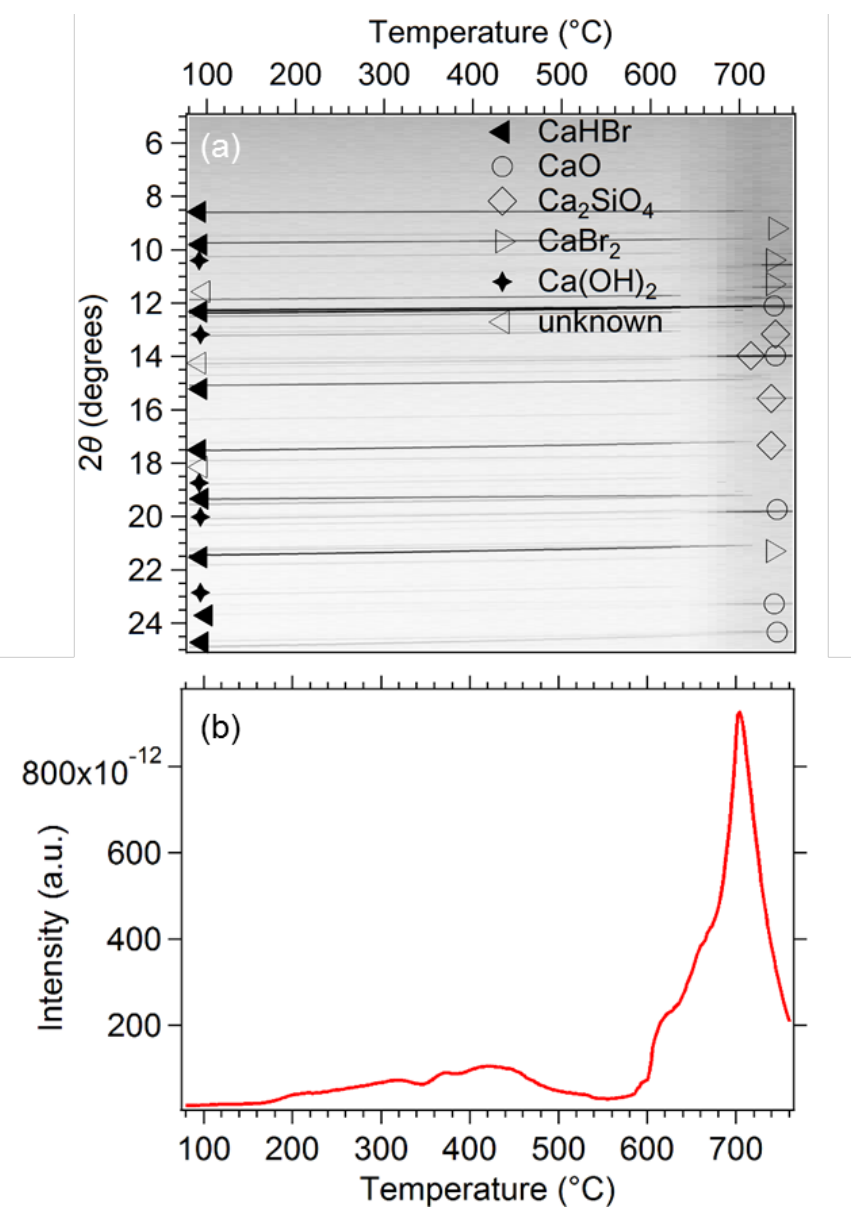

Fig. 4: In situ SR-XRD (a) for $\mathrm{CaHBr}, \lambda=0.589741 \AA$, and (b) simultaneous thermal analysis by temperature programmed desorption-mass spectrometry (TPD-MS).

It is evident from in-situ SR-XRD (Fig. 5(a)) that CaHI commences decomposition at $700{ }^{\circ} \mathrm{C}$. At the same temperature, an onset of hydrogen detection is observed in the TPD-MS data (Fig. 5 (b)), and an endothermic peak is recorded by DSC (Fig. S8). At $\sim 780^{\circ} \mathrm{C}$, all diffraction peaks related to the CaHI phase have disappeared from the in-situ SR-XRD patterns (Fig. 5 (a)) and the maxima of 
the hydrogen peak in the TPD-MS curve is observed. This indicates that hydrogen begins to desorb from the $\mathrm{CaHI}$ just before its melting point to form $\mathrm{Ca}$ and $\mathrm{CaI}_{2}$ as the final product according to reaction (3).

$2 \mathrm{CaHI} \rightarrow \mathrm{Ca}+\mathrm{CaI}_{2}+\mathrm{H}_{2}$

$\mathrm{CaI}_{2}$ is molten at this temperature and hard to identify. $\mathrm{CaSiO}_{4}$ also forms at this temperature. The reaction products of the decomposed $\mathrm{CaHI}$ are evident in the XRD diffraction pattern after its TPD measurement (Fig. S11)
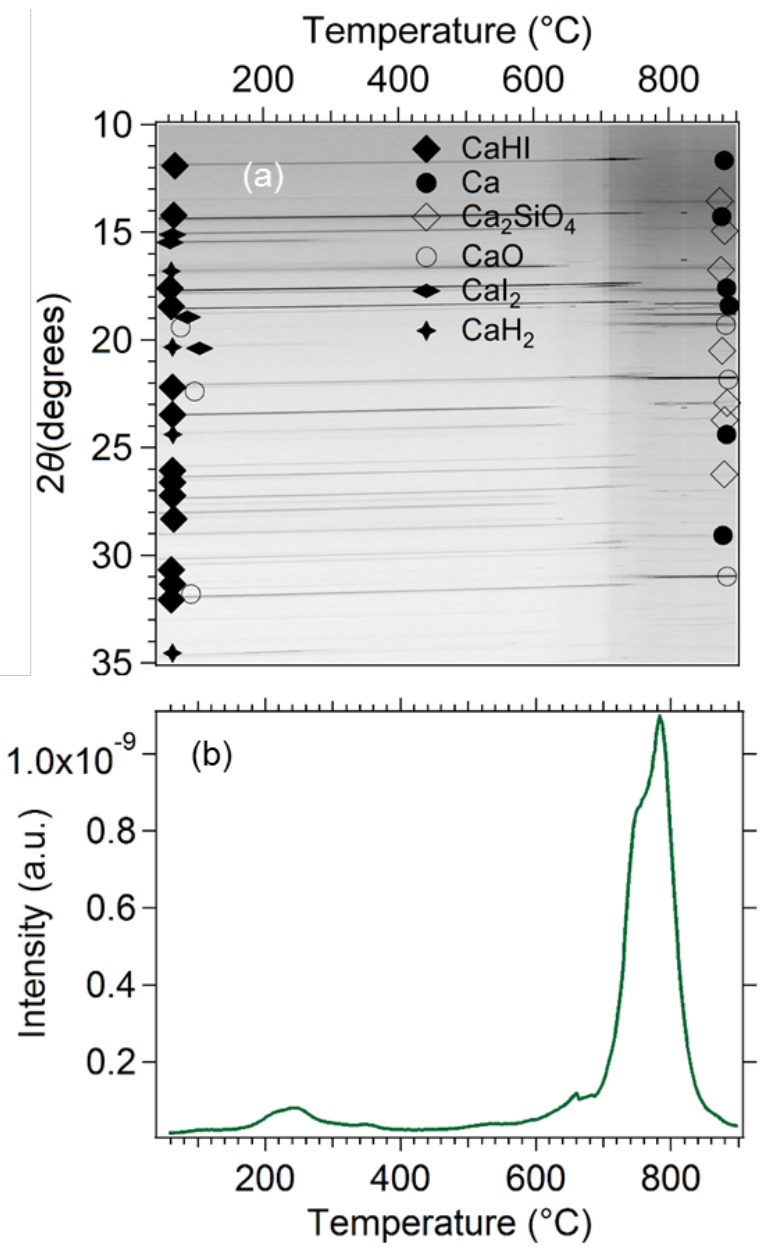

Fig. 5: In situ SR-XRD (a) for CaHI, $\lambda=0.9218749 \AA$, and (b) simultaneous thermal analysis by temperature programmed desorption-mass spectrometry (TPD-MS).

The volumetric TPD curves of all samples versus time and temperature are presented in Fig.6. The hydrogen capacity for all samples has been normalised to the desorbed hydrogen 
quantity for results to be easily comparable (wt $\%$ is reported in Table 1$)$. It is noticeable that $\mathrm{CaH}_{2}$ exhibits the slowest reaction kinetics upon heating in comparison to the rest of the samples, reaching its maximum desorption value at $400 \mathrm{~min}\left(200 \mathrm{~min}\right.$ after reaching $\left.850{ }^{\circ} \mathrm{C}\right)$. A slight improvement in the reaction kinetics is observed for $\mathrm{CaHCl}$, which has reached a stable rate at $300 \mathrm{~min}\left(100 \mathrm{~min}\right.$ after reaching $\left.850{ }^{\circ} \mathrm{C}\right)$. In contrast, both $\mathrm{CaHBr}$ and $\mathrm{CaHI}$ have reached their maximum hydrogen desorption values within the first $200 \mathrm{~min}$ of the experiment (just reaching $850{ }^{\circ} \mathrm{C}$ ), having $50 \%$ faster reaction kinetics in comparison to $\mathrm{CaH}_{2}$. The only difference between these two samples is that $\mathrm{CaHBr}$ starts to desorb hydrogen at lower temperatures compared to $\mathrm{CaHI}$ but then slows down between $600-850{ }^{\circ} \mathrm{C}$, whereas $\mathrm{CaHI}$ shows a steady hydrogen desorption rate between $200-850^{\circ} \mathrm{C}$. The addition of calcium halide salts to $\mathrm{CaH}_{2}$ to form these new compounds has destabilised $\mathrm{CaH}_{2}$ to decompose at lower temperatures, showing a slight improvement in their reaction kinetics. The released hydrogen at lower temperatures $\left(400-500^{\circ} \mathrm{C}\right)$, as also seen in the TPD-MS (Fig. 2-5) figures, it may be due to the presence of impurities in all samples and decompose within that temperature range. The theoretical and experimental values of the desorbed $\mathrm{H}_{2} \mathrm{wt} \%$ are presented in Table 1 as well as their maximum released hydrogen pressures. It is noticeable that all samples except $\mathrm{CaHCl}$ when heated did not reach the theoretical values of their $\mathrm{H}_{2} \mathrm{wt} \%$. This is due to: (i) the impurities from the starting material $(\mathrm{CaO})$, (ii) un-reacted products $\left(\mathrm{CaH}_{2}\right.$ and $\left.\mathrm{CaI}_{2}\right)$ for the CaHI sample, (iii) slow reaction kinetics, since all samples were kept at $850{ }^{\circ} \mathrm{C}$ for $4 \mathrm{~h}$, indicating that more time was required for their complete desorption, and (iv) thermodynamic limitations specifically for $\mathrm{CaH}_{2} \cdot \mathrm{CaH}_{2}$ decomposes at $1100{ }^{\circ} \mathrm{C}$ under 1 bar of $\mathrm{H}_{2}$ pressure. Since the TPD experiment was done at $850{ }^{\circ} \mathrm{C}$ and the $\mathrm{H}_{2}$ pressure at that temperature was 0.72 bar, implies that $\mathrm{CaH}_{2}$ was not able to decompose further due to its thermodynamic limitations. The $\mathrm{H}_{2}$ pressure was too high and the temperature was too low in order for the system to be thermodynamically driven. The experimental value of the desorbed $\mathrm{H}_{2}$ for $\mathrm{CaHCl}$ is slightly 
higher than the theoretical one. This may be attributed to the fact that this particular sample desorbed the largest amount of $\mathrm{H}_{2}$ between 180 and $320{ }^{\circ} \mathrm{C}$ in comparison to the rest of the samples, besides its main desorption at higher temperatures.

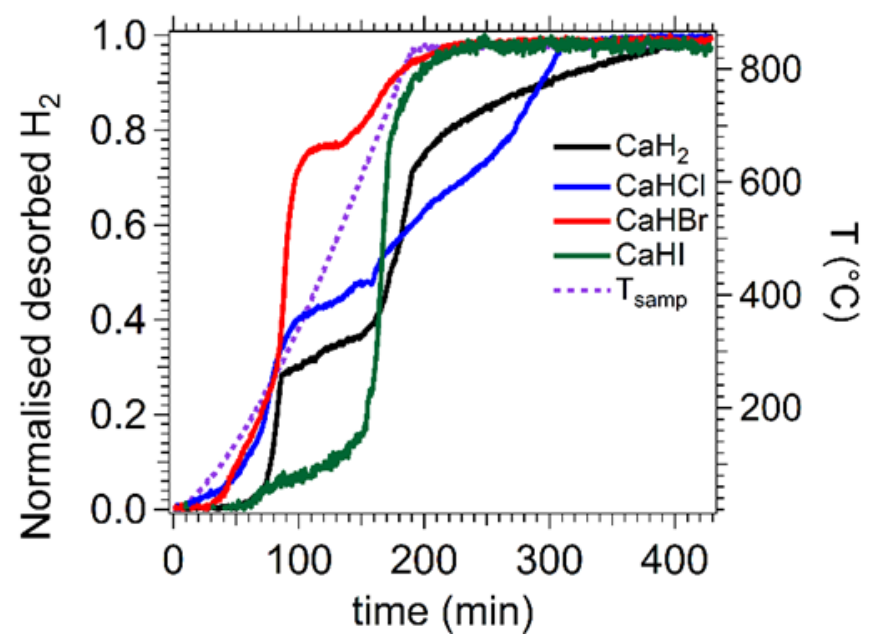

Fig. 6: Temperature programmed desorption (TPD) results for $\mathrm{CaH}_{2}, \mathrm{CaHCl}, \mathrm{CaHBr}$ and $\mathrm{CaHI}$.

Table 1

Experimental TPD and theoretical quantity of released $\mathrm{H}_{2}$ of the $\mathrm{CaH}_{2}, \mathrm{CaHCl}, \mathrm{CaHBr}$ and CaHI. All samples were heated from room temperature to $850{ }^{\circ} \mathrm{C}$ with a ramping rate of $5{ }^{\circ} \mathrm{C}$ $\min ^{-1}$ before reaching isothermal conditions at $850{ }^{\circ} \mathrm{C}$ for $4 \mathrm{~h}$. TPD-MS measurements were conducted under Ar flow and were heated from room temperature to $1000{ }^{\circ} \mathrm{C}$ with a ramping rate of $10^{\circ} \mathrm{C} \min ^{-1}$.

\begin{tabular}{ccccc}
\hline Sample & $\begin{array}{c}\text { Experimental } \mathrm{H}_{2} \\
\text { capacity }(\mathrm{wt} \%)\end{array}$ & $\begin{array}{c}\text { Theoretical } \mathrm{H}_{2} \\
\text { capacity }(\mathrm{wt} \%)\end{array}$ & $\begin{array}{c}\text { Desorbed } \mathrm{H}_{2} \\
\text { Pressure }(\text { bar })\end{array}$ & $\begin{array}{c}\text { Temperature } \\
\text { corresponding to main } \\
\mathrm{H}_{2} \text { peak in TPD-MS } \\
\left({ }^{\circ} \mathrm{C}\right)\end{array}$ \\
\hline $\mathrm{CaH}{ }_{2}$ & 0.80 & 4.79 & 0.72 & 816 \\
\hline $\mathrm{CaHCl}$ & 1.49 & 1.32 & 0.89 & 740 \\
\hline $\mathrm{CaHBr}$ & 0.61 & 0.83 & 0.47 & 697 \\
\hline $\mathrm{CaHI}$ & 0.45 & 0.60 & 0.27 & 726
\end{tabular}


Pseudo PCI measurements near the desired operating temperatures $\left(650{ }^{\circ} \mathrm{C}\right.$ for $\mathrm{CaHCl}$ and $\mathrm{CaHBr}$, and at $700{ }^{\circ} \mathrm{C}$ for $\left.\mathrm{CaHI}\right)$ were performed to gauge an estimated range of the operating pressures (Fig. 7). The reason for this choice and not performing PCI measurements at all samples between 650 and $750{ }^{\circ} \mathrm{C}$ is due to a combination of factors related to: (i) the limitation of $\mathrm{H}_{2}$ pressure to 15 bar when conducting these measurements, due to a $\mathrm{SiC}$ sample holder being used at these high temperatures instead of a stainless steel holder to eliminate $\mathrm{H}_{2}$ losses from the sample cell; (ii) all as-prepared samples exhibited very slow reaction kinetics (Fig. $\mathrm{S} 12-\mathrm{S} 14$ ) and sintering issues above $650{ }^{\circ} \mathrm{C}$, and (iii) the melting temperatures as observed from the in situ $\mathrm{SR}-\mathrm{XRD}$ for $\mathrm{CaHCl}, \mathrm{CaHBr}$ and $\mathrm{CaHI}$ were about $\sim 730, \sim 680$ and $\sim 710{ }^{\circ} \mathrm{C}$ respectively, meaning that the thermodynamics will changes at those temperatures. This limits the accurate temperature range for which accurate PCI measurements can be obtained. When CaHI was heated to $650{ }^{\circ} \mathrm{C}$ for the PCI measurements, no equilibrium pressures were observed, thus an increase in temperature to $700{ }^{\circ} \mathrm{C}$ was necessary.

SEM images of the as-prepared CaHI after an attempted PCI measurement at $650{ }^{\circ} \mathrm{C}$ (Fig. 8) were obtained, to confirm the sintering issue of these samples that inhibits their proper thermodynamic analysis and determination of their enthalpies and entropies. It is clear that the as-prepared $\mathrm{CaHI}$ is in the form of single crystals in the shape of rods (Fig. 8(a,b)) and when it is heated to $650{ }^{\circ} \mathrm{C}$, the crystals sinter and agglomerate to large particles (Fig. 8(c,d)). This sintering effect hindered the rehydrogenation of all samples. 


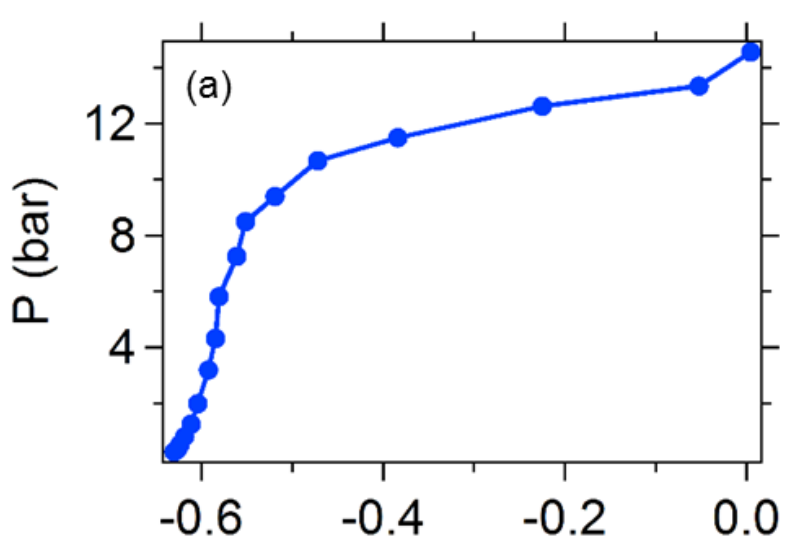

$\mathrm{H}_{2}$ wt $\%$ desorbed



$\mathrm{H}_{2}$ wt $\%$ desorbed

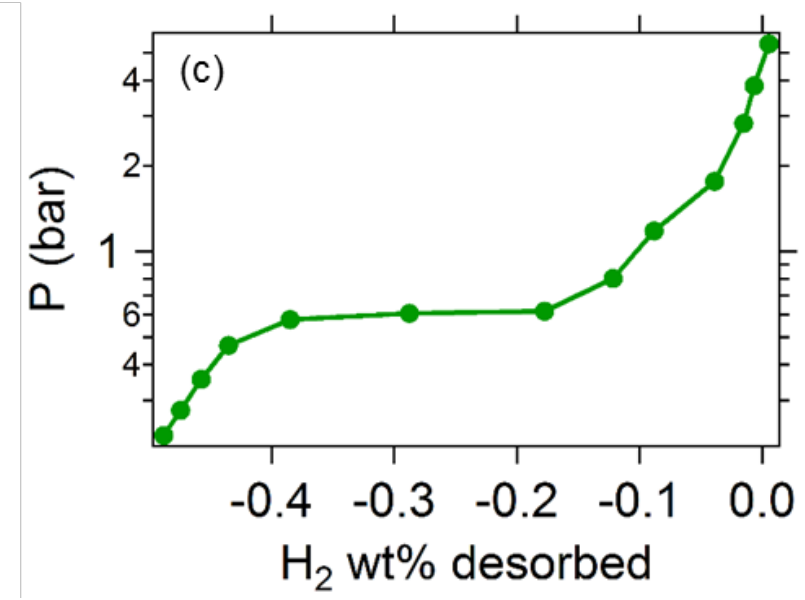

Fig. 7: Pseudo Pressure composition isotherms (PCI) for (a) $\mathrm{CaHCl}$, (b) $\mathrm{CaHBr}$ at $650{ }^{\circ} \mathrm{C}$ and (c) $\mathrm{CaHI}$ at $700{ }^{\circ} \mathrm{C}$, each data point is equal to an $8 \mathrm{~h}$ step size. 


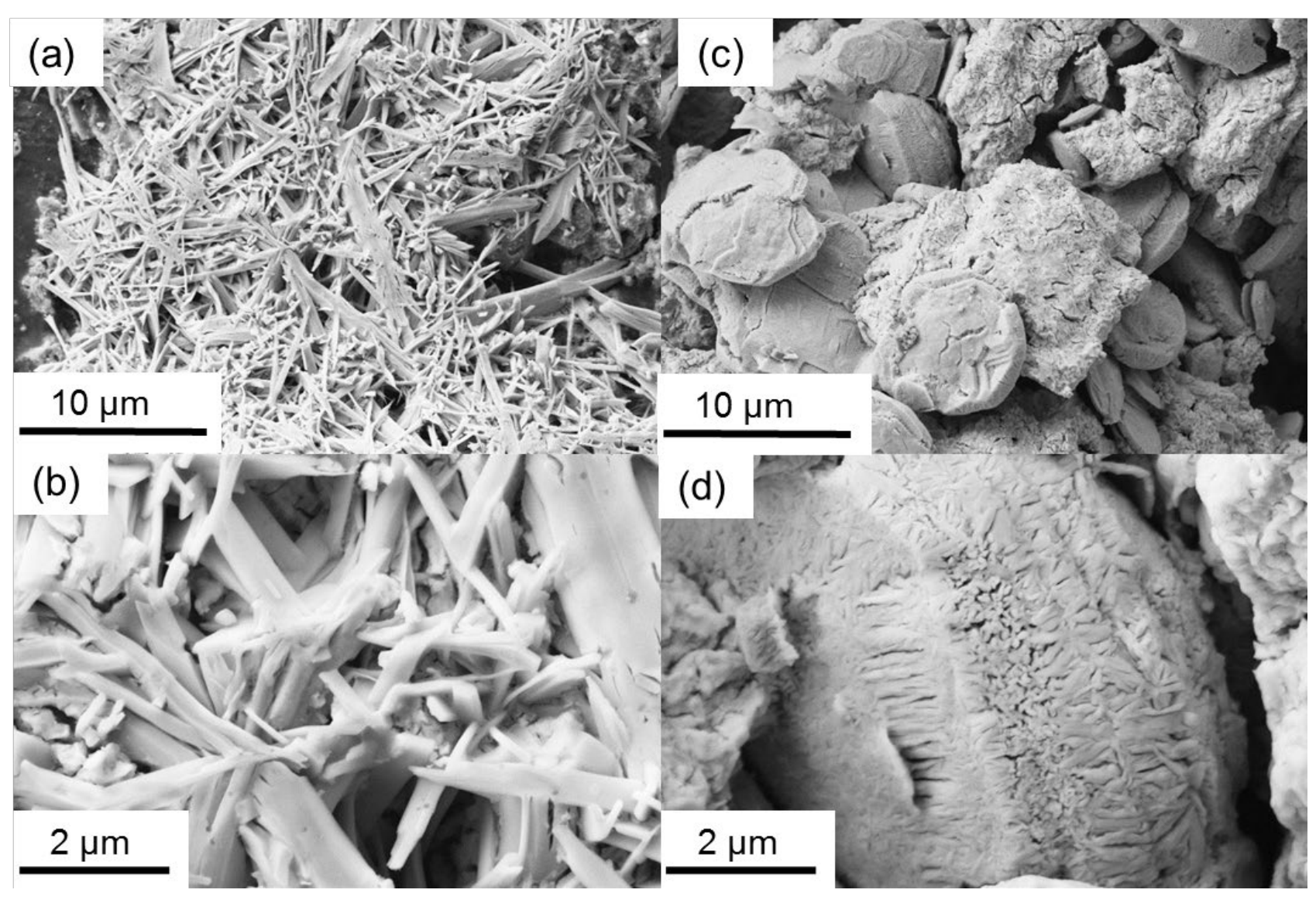

Fig.8: (a, b) SEM micrographs of CaHI as-prepared and (c, d) after PCI measurements at 650 ${ }^{\circ} \mathrm{C}$.

\section{Conclusions}

$\mathrm{CaHCl}, \mathrm{CaHBr}$ and $\mathrm{CaHI}$ were synthesised by ball milling $\mathrm{CaH}_{2}$ with the respective calcium halide salts $\left(\mathrm{CaCl}_{2}, \mathrm{CaBr}_{2}, \mathrm{CaI}_{2}\right)$, and then annealing the mixtures at $450{ }^{\circ} \mathrm{C}$ at 100 bar $\mathrm{H}_{2}$ for 12, 24 and $48 \mathrm{~h}$ correspondingly. Their potential use as integrated thermal batteries for the third generation of CSP plants that operate at temperatures between 600 and $800{ }^{\circ} \mathrm{C}$, was investigated by in situ SR-XRD, TPD-MS, TPD and DSC. All three new compounds exhibited both faster reaction kinetics in comparison to $\mathrm{CaH}_{2}$, and lower decomposition temperatures. Specifically, $\mathrm{CaHCl}, \mathrm{CaHBr}$ and $\mathrm{CaHI}$ started to decompose at 730,700 and $770{ }^{\circ} \mathrm{C}$ respectively. The equilibrium pressures of these compounds at $650{ }^{\circ} \mathrm{C}$ were within the range 
of 1 to 10 bar, as required for the next generation of CSP plants. The determination of the enthalpy and entropy of all calcium hydride halide samples could not be determined due to ultra-slow reaction kinetics during the PCI measurements and sintering problems, even though all samples had faster reaction kinetics in comparison to pure $\mathrm{CaH}_{2}$. The incorporation of a catalysts to these systems may increase their reaction kinetics, making it possible to determine their enthalpy and entropy through PCI measurements. Halide substituted $\mathrm{CaH}_{2}$ materials show improved operational temperatures compared to the parent compound, but have lower hydrogen content by mass. This means that theoretically, twice the quantity of calcium is required to allow the same quantity of hydrogen to react. In addition, the material will weigh more due to the additional mass of a halogen. Despite these issues, there is still potential in using $\mathrm{CaH}$-halide materials as thermal energy stores due to their high volumetric energy storage densities and favourable operation temperatures

\section{Acknowledgements}

CEB, TDH and MVS acknowledge the financial support of the Australian Research Council for ARC Linkage grant LP150100730. MP acknowledges the financial support of ARC Future Fellowship FT160100303. CEB acknowledges the financial support of the Australian Research Council for ARC LIEF grants LE0775551 and LE0989180 which enabled the TPD and PCI measurements to be undertaken. Part of this research was undertaken using the EM instrument ARC LIEF grant LE0775553 at the John de Laeter Centre, Curtin University. The in-situ X-ray synchrotron powder diffraction data was collected on the Powder Diffraction beamline at the Australian Synchrotron.

\section{References}

[1] H.L. Zhang, J. Baeyens, J. Degrève, G. Cacères, Concentrated solar power plants: Review and design methodology, Renew. Sust. Energ. Rev. 22 (2013) 466-481. 
[2] Y. Tian, C.Y. Zhao, A review of solar collectors and thermal energy storage in solar thermal applications, Appl. Energy, 104 (2013) 538-553.

[3] X. Chen, Z. Zhang, C. Qi, X. Ling, H. Peng, State of the art on the high-temperature thermochemical energy storage systems, Energy Convers. Manag. 177 (2018) 792-815.

[4] M.H. Ahmadi, M. Ghazvini, M. Sadeghzadeh, M. Alhuyi Nazari, R. Kumar, A. Naeimi, T. Ming, Solar power technology for electricity generation: A critical review, Energy Sci. Eng. 6 (2018) 340-361.

[5] P.A. Ward, C. Corgnale, J.A. Teprovich, T. Motyka, B. Hardy, D. Sheppard, C. Buckley, R. Zidan, Technical challenges and future direction for high-efficiency metal hydride thermal energy storage systems, Appl. Phys. A 122 (2016) 462.

[6] D.N. Harries, M. Paskevicius, D.A. Sheppard, T.E.C. Price, C.E. Buckley, Concentrating Solar Thermal Heat Storage Using Metal Hydrides, Proc. IEEE 100 (2012) 539-549.

[7] T. Bauer, N. Pfleger, N. Breidenbach, M. Eck, D. Laing, S. Kaesche, Material aspects of Solar Salt for sensible heat storage, Appl. Energy, 111 (2013) 1114-1119.

[8] M. Medrano, A. Gil, I. Martorell, X. Potau, L.F. Cabeza, State of the art on hightemperature thermal energy storage for power generation. Part 2 - Case studies, Renew. Sust. Energ. Rev. 14 (2010) 56-72.

[9] S. Riahi, Y. Jovet, W.Y. Saman, M. Belusko, F. Bruno, Sensible and latent heat energy storage systems for concentrated solar power plants, energy efficiency comparison, Sol. Energy 180 (2019) 104-115.

[10] B. D'Aguanno, M. Karthik, A.N. Grace, A. Floris, Thermostatic properties of nitrate molten salts and their solar and eutectic mixtures, Sci. Rep. 8 (2018) 10485.

[11] R. Jacob, F. Bruno, Review on shell materials used in the encapsulation of phase change materials for high temperature thermal energy storage, Renew. Sust. Energ. Rev. 48 (2015) 7987. 
[12] D. Zhou, P. Eames, Thermal characterisation of binary sodium/lithium nitrate salts for latent heat storage at medium temperatures, Sol. Energy Mater. Sol. Cells 157 (2016) 10191025.

[13] C.Y. Zhao, D. Zhou, Z.G. Wu, Heat Transfer Enhancement of Phase Change Materials (PCMs) in Low and High Temperature Thermal Storage by Using Porous Materials, 14th International Heat Transfer Conference 7 (2010) 435-441.

[14] U. Pelay, L. Luo, Y. Fan, D. Stitou, M. Rood, Thermal energy storage systems for concentrated solar power plants, Renew. Sust. Energ. Rev. 79 (2017) 82-100.

[15] R. Sioshansi, P. Denholm, The Value of Concentrating Solar Power and Thermal Energy Storage, IEEE T. Sustain. Energ. 1 (2010) 173-183.

[16] W.E. Wentworth, E. Chen, Simple thermal decomposition reactions for storage of solar thermal energy, Sol. Energy 18 (1976) 205-214.

[17] K. Kyaw, H. Matsuda, M. Hasatani, Applicability of Carbonation/Decarbonation Reactions to High-Tempereture Thermal Energy Storage and Temperature Upgrading, J. Chem. Eng. Jpn 29 (1996) 119-125.

[18] G. Ervin, Solar heat storage using chemical reactions, J. Solid State Chem. 22 (1977) 5161.

[19] A. Gil, M. Medrano, I. Martorell, A. Lázaro, P. Dolado, B. Zalba, L.F. Cabeza, State of the art on high temperature thermal energy storage for power generation. Part 1 - Concepts, materials and modellization, Renew. Sust. Energ. Rev. 14 (2010) 31-55.

[20] M. Paskevicius, D.A. Sheppard, K. Williamson, C.E. Buckley, Metal hydride thermal heat storage prototype for concentrating solar thermal power, Energy 88 (2015) 469-477.

[21] T.D. Humphries, K.T. Møller, W.D.A. Rickard, M.V. Sofianos, S. Liu, C.E. Buckley, M. Paskevicius, Dolomite: a low cost thermochemical energy storage material, J. Mater. Chem. A 7 (2019) 1206-1215. 
[22] D.A. Sheppard, M. Paskevicius, T.D. Humphries, M. Felderhoff, G. Capurso, J. Bellosta von Colbe, M. Dornheim, T. Klassen, P.A. Ward, J.A. Teprovich, C. Corgnale, R. Zidan, D.M. Grant, C.E. Buckley, Metal hydrides for concentrating solar thermal power energy storage, Appl. Phys. A 122 (2016) 395.

[23] L. André, S. Abanades, L. Cassayre, Mixed Co, Cu and Mn-based metal oxides for thermochemical energy storage application, AIP Conf. Proc. 2033 (2018) 100003.

[24] K.M. Nicholson, D.S. Sholl, First-principles screening of complex transition metal hydrides for high temperature applications, Inorg. Chem. 53 (2014) 11833-11848.

[25] V.A. Yartys, M.V. Lototskyy, E. Akiba, R. Albert, V.E. Antonov, J.R. Ares, M. Baricco, N. Bourgeois, C.E. Buckley, J.M. Bellosta von Colbe, J.C. Crivello, F. Cuevas, R.V. Denys, M. Dornheim, M. Felderhoff, D.M. Grant, B.C. Hauback, T.D. Humphries, I. Jacob, T.R. Jensen, P.E. de Jongh, J.M. Joubert, M.A. Kuzovnikov, M. Latroche, M. Paskevicius, L. Pasquini, L. Popilevsky, V.M. Skripnyuk, E. Rabkin, M.V. Sofianos, A. Stuart, G. Walker, H. Wang, C.J. Webb, M. Zhu, Magnesium based materials for hydrogen based energy storage: Past, present and future, Int. J. Hydrog. Energy 44 (2019) 7809-7859.

[26] L. Poupin, T.D. Humphries, M. Paskevicius, C.E. Buckley, A thermal energy storage prototype using sodium magnesium hydride, Sustain. Energ. Fuels 3 (2019) 985-995.

[27] T.D. Humphries, D.A. Sheppard, G. Li, M.R. Rowles, M. Paskevicius, M. Matsuo, K.-F. Aguey-Zinsou, M.V. Sofianos, S.-i. Orimo, C.E. Buckley, Complex hydrides as thermal energy storage materials: characterisation and thermal decomposition of $\mathrm{Na}_{2} \mathrm{Mg}_{2} \mathrm{NiH}_{6}, \mathrm{~J}$. Mater. Chem. A 6 (2018) 9099-9108.

[28] M.S. Tortoza, T.D. Humphries, D.A. Sheppard, M. Paskevicius, M.R. Rowles, M.V. Sofianos, K.F. Aguey-Zinsou, C.E. Buckley, Thermodynamics and performance of the Mg-HF system for thermochemical energy storage applications, Phys. Chem. Chem. Phys. 20 (2018) 2274-2283. 
[29] K. Møller, D. Sheppard, D. Ravnsbæk, C. Buckley, E. Akiba, H.-W. Li, T. Jensen, Complex Metal Hydrides for Hydrogen, Thermal and Electrochemical Energy Storage, Energies 10 (2017) 1645.

[30] US Department of Energy, D.O.E. DE-FOA-0000471: High energy advanced thermal storage (HEATS) (2011). https://arpa-e.energy.gov/?q=arpa-e-programs/heats (accessed 26 July 2019).

[31] SunShot Vision Study, Cost and Performance (US Department of Energy, 2012). https://www.energy.gov/eere/solar/sunshot-vision-study (accessed 26 July 2019).

[32] U. S. Department of Energy under DE-FG36-08GO18145, Thermochemical heat storage for concentrated solar power (2011). https://www.osti.gov/biblio/1039304-thermochemicalheat-storage-concentrated-solar-power (accessed 26 July 2019).

[33] M.T. Islam, N. Huda, A.B. Abdullah, R. Saidur, A comprehensive review of state-of-theart concentrating solar power (CSP) technologies: Current status and research trends, Renew. Sust. Energ. Rev. 91 (2018) 987-1018.

[34] M. Sarvghad, S. Delkasar Maher, D. Collard, M. Tassan, G. Will, T.A. Steinberg, Materials compatibility for the next generation of Concentrated Solar Power plants, Energy Storage Mater. 14 (2018) 179-198.

[35] E. Rönnebro, G. Whyatt, M. Powell, M. Westman, F. Zheng, Z. Fang, Metal Hydrides for High-Temperature Power Generation, Energies 8 (2015) 8406-8430.

[36] K. Manickam, P. Mistry, G. Walker, D. Grant, C.E. Buckley, T.D. Humphries, M. Paskevicius, T. Jensen, R. Albert, K. Peinecke, M. Felderhoff, Future perspectives of thermal energy storage with metal hydrides, Int. J. Hydrog. Energy 44 (2019) 7738-7745.

[37] R.E. Gawley, A. Davis, Calcium Hydride, e-EROS (2001) John Wiley \& Sons.

[38] R.W. Curtis, P. Chiotti, Thermodynamic Properties of Calcium Hydride, J. Phys. Chem. 67 (1963) 1061-1065. 
[39] Kandavel Manickam, Priyen Mistry, Gavin Walker, David Grant, Craig E. Buckley, Terry D. Humphries, Mark Paskevicius, Torben Jensen, Rene Albert, Kateryna Peinecke, Michael Felderhoff, Future perspectives of thermal energy storage withmetal hydrides, Int. J. Hydrog. Energy 44 (2019) 7738-7745.

[40] A.D. Bulanov, O.Y. Troshin, V.V. Balabanov, Synthesis of High-Purity Calcium Hydride, Russ. J. Appl. Chem. 77 (2004) 875-877.

[41] A.J. Hurd, D.W. Schaefer, D.M. Smith, S.B. Ross, A. Le Méhauté, S. Spooner, Surface areas of fractally rough particles studied by scattering, Phys. Rev. B 39 (1989) 9742-9745. [42] G.A. Meerson, O.P. Kolchin, Mechanism of the reduction of zirconium and titanium oxides by calcium hydride, Sov. J. At. En. 2 (1957) 305-312.

[43] P. Rittmeyer, U. Wietelmann, Hydrides, Ullmann's Encyclopedia of Industrial Chemistry $18(2000)$ 103-132.

[44] T.D. Humphries, D.A. Sheppard, M.R. Rowles, M.V. Sofianos, C.E. Buckley, Fluoride substitution in sodium hydride for thermal energy storage applications, J. Mater. Chem. A 4 (2016) 12170-12178.

[45] D. A. Sheppard, M. Paskevicius, P. Javadian, I. J. Davis, C. E. Buckley, Methods for accurate high-temperature Siverts-type hydrogen measurements of metal hydrides, J. Alloys Compd. 787 (2019) 1225-1237.

[46] P. Ehrlich, B. Alt, L. Gentsch, Über die Hydridchloride der Erdalkalimetalle, Z. Anorg. Allg. Chem. 283 (1956) 58-73.

[47] H.P. Beck, A. Limmer, Die Verfeinerung der Kristallstrukturen von $\mathrm{CaHCl}, \mathrm{SrHCl}$, BaHCl, BaHBr und BaHI, Z. Anorg. Allg. Chem. 502 (1983) 185-190.

[48] M. Ayadi, M. Sieskind, Crystal growth and Raman spectra of $\mathrm{CaHCl}$ and $\mathrm{CaDCl}$, J. Raman Spectrosc. 18 (1987) 147-149. 
[49] R. Sridharan, K.H. Mahendran, T. Gnanasekaran, G. Periaswami, U.V. Varadaraju, C.K. Mathews, On the phase relationships and electrical properties in the $\mathrm{CaCl}_{2}-\mathrm{CaH}_{2}$ system, $\mathrm{J}$. Nucl. Mater. 223 (1995) 72-79.

[50] C.V. Vishnu Vardhan, S. Ghosh, S. Nagaraj, R. Sridharan, T. Gnanasekaran, Phase diagram study of $\mathrm{CaBr}_{2}-\mathrm{CaHBr}$ system, J. Therm. Anal. Calorim. 112 (2012) 127-131.

[51] K.S. Wallwork, B.J. Kennedy, D. Wang, The High Resolution Powder Diffraction Beamline for the Australian Synchrotron, AIP Conf. Proc. 879 (2007) 879-882.

[52] P.D. Pathak, N.G. Vasavada, Thermal expansion of $\mathrm{NaCl}, \mathrm{KCl}$ and $\mathrm{CsBr}$ by X-ray diffraction and the law of corresponding states, Acta Cryst. A 26 (1970) 655-658.

[53] I.-K. Suh, H. Ohta, Y. Waseda, High-temperature thermal expansion of six metallic elements measured by dilatation method and X-ray diffraction, J. Mater. Sci. 23 (1988) 757760.

[54] B.R.S. Hansen, K.T. Møller, M. Paskevicius, A.-C. Dippel, P. Walter, C.J. Webb, C. Pistidda, N. Bergemann, M. Dornheim, T. Klassen, J.-E. Jørgensen, T.R. Jensen, In situX-ray diffraction environments for high-pressure reactions, J. Appl. Crystallogr. 48 (2015) 12341241.

[55] B. Schmitt, C. Brönnimann, E.F. Eikenberry, F. Gozzo, C. Hörmann, R. Horisberger, B. Patterson, Mythen detector system, Nucl. Instrum. Methods Phys. Res. 501 (2003) 267-272. [56] M. Paskevicius, D.A. Sheppard, C.E. Buckley, Thermodynamic changes in mechanochemically synthesized magnesium hydride nanoparticles, J. Am. Chem. Soc., 132 (2010) 5077-5083.

[57] D.A. Sheppard, M. Paskevicius, P. Javadian, I.J. Davies, C.E. Buckley, Methods for accurate high-temperature Sieverts-type hydrogen measurements of metal hydrides, J. Alloys Compd., 787 (2019) 1225-1237. 
[58] J.A. Alonso, M. Retuerto, J. Sanchez-Benitez, M.T. Fernández-Díaz, Crystal structure and bond valence of $\mathrm{CaH}_{2}$ from neutron powder diffraction data, Z. Kristallogr. Cryst. Mater 225 (2010) 225-229.

[59] D.T. Peterson, V.G. Fattore, Calcium-Calcium Hydride Phase System, J. Phys. Chem. 65 (1961) 2062-2064.

[60] N. Yamaguchi, Y. Masuda, Y. Yamada, H. Narusawa, C. Han-Cheol, Y. Tamaki, T. Miyazaki, Synthesis of $\mathrm{CaO}-\mathrm{SiO}_{2}$ Compounds Using Materials Extracted from Industrial Wastes, Open J. Inorg. Non-Met. Mater. 05 (2015) 1-10. 